\title{
Soil Physical Attributes in Long-Term Soil Management Systems (Tillage and No-till)
}

\author{
Venâncio Rodrigues e Silva ${ }^{1}$, José Luiz Rodrigues Torres ${ }^{2}$, Danyllo Denner de Almeida Costa ${ }^{1}$, \\ Bruna de Souza Silveira ${ }^{2}$, Dinamar Márcia da Silva Vieira ${ }^{1} \&$ Ernane Miranda Lemes ${ }^{1}$ \\ ${ }^{1}$ Instituto de Ciência Agrárias, Universidade Federal de Uberlândia, Campus Glória, Uberlândia, Brazil \\ ${ }^{2}$ Instituto Federal do Triângulo Mineiro, Campus Uberaba, Uberaba, Brazil \\ Correspondence: Ernane Miranda Lemes, Instituto de Ciência Agrárias, Universidade Federal de Uberlândia, \\ Road BR 050, km 78, Uberlândia, Brazil. Tel: 55-34-2512-6701. E-mail: ernanefito@gmail.com
}

Received: January 11, 2020

doi:10.5539/jas.v12n4p194
Accepted: February 17, $2020 \quad$ Online Published: March 15, 2020

URL: https://doi.org/10.5539/jas.v12n4p194

\begin{abstract}
The period of implantation of the no-tillage system (NTS) is a fundamental factor to the dimension of the changes that occur to the soil's physical, chemical and biological attributes. Thus, the objective of this study was to evaluate the soil changes to the physical attributes and correlate the results to the soil organic matter in areas of different long-term soil management. The study was set as a completely randomised design, in a $4 \times 4$ factorial scheme, with four management systems [5 years NTS (NTS5); 17 years NTS (NTS17); conventional tillage system for 20 years (CTS20); native area (NA)], and four soil depths (0-0.05, 0.05-0.1, 0.1-0.2, 0.2-0.4 m), with five repetitions. Soil mechanical resistance to root penetration (RP), bulk density (SD), volumetric moisture (VM), macro (Ma), microporosity (Mi) and total porosity (TP), and the aggregation parameters were evaluated. The CTS20, NTS5 and NTS17 presented superior SD in the most superficial soil layers, which was not yet causing resistance to root development. The SD was the only physical attribute that correlated significantly with all the other soil attributes evaluated, indicating the importance of such attribute to evaluate soil quality to crops. The soil physical attributes found in the Cerrado native area followed the sequence of similarities: no-tillage system with 17 years (most similar), with five years and the conventional tillage system (less similar). The changes caused by the anthropic activity in the soil's physical attributes are more pronounced and perceptible in soil depths up to $0.2 \mathrm{~m}$.
\end{abstract}

Keywords: conventional soil tillage, soil physics; soil compaction, soil porosity, native area

\section{Introduction}

The agricultural production in Brazil was, until a few decades ago, based on soil-revolving system (conventional tillage system), where successive harrowings prepared the soil to receive the seeds and to allow better soil conditions for plant development. However, this soil management system, when used for several years, disturbs the soil, causes erosions and the formation of compressed soil layers, thus, subjecting soil to different forms of erosion (Carvalho et al., 2010). This soil worsening condition with crop cultivation in tillage areas has motivated the search and research for cropping systems that are less damaging to the environment.

From that motivation, the cultivation of areas with minimum soil tillage and no-tillage system (NTS) of soil management had evolved. The NTS is considered a conservationist system that keeps crop residues on the soil surface and not incorporated into it (Rodrigues et al., 2018). This conservationist system provides positive changes to the physical, chemical and biological soil attributes in the Brazilian Cerrado biome (Savannah-like biome) (Mazetto Junior et al., 2019).

Despite the soil benefits provided by the NTS, compaction of the subsurface soil layers may occur. This soil physical impediment is due to cropping operations with heavy machinery and to operations on occasions of inappropriate soil moisture (Santos et al., 2014). Soil compaction reduces macroporosity, total porosity and pore continuity in soil, causing the reorganization and distribution of soil particles and soil aggregates. These changes negatively alter air and water movement in soil finally constraining plant root development (Rossetti et al., 2012; Mcphee et al., 2015; Torres et al., 2015a; Moraes et al., 2016). 
Soil structuring is achieved after a few years of NTS implantation. This system improves soil strength to support traffic without presenting significant compressibility due to denser and resistant aggregates (Stone et al., 2006). Reis et al. (2016) and Torres et al. (2019) observed that the reductions in soil density and soil compaction were related to increments of soil porosity in areas cultivated under NTS with increasing periods of system implantation.

The period of implantation of the NTS is fundamental to improve the changes to the physical and chemical attributes of the soil. In the first five years, the soil is in its initial phase of restructuring to the new system (NTS); the accumulations of plant debris on soil surface begin, remnants of the root system also accumulate in soil subsurface, contributing to restoring microbial activity. The transition phase to system stability occurs between 5 and 10 years after NTS implantation. The consolidation phase occurs between 10 and 20 years; after that, the system enters the maintenance phase ( $>20$ years), where the NTS will be expressing its full potential benefits (Sá et al., 2004).

In natural conditions, the soil structure stability is elevated and depends on the climate, soil texture, organic matter dynamics, physical and biological phenomena that interfere in the flocculation and cementation of soil aggregates (Loss et al., 2012; Tesfahunegn \& Gebru, 2020). However, in the agricultural environment, the maintenance of the soil structure mainly depends on the management system and on the plant species cultivated, which directly interferes with soil physical and biological activity, factors that affect the soil aggregation (Loss et al., 2019).

Studies were already carried out in areas cultivated under NTS after a long period of introduction of the system. However, in the Brazilian Cerrado, the same study with old NTS systems has not occurred yet. In this context, the objective of this study was to evaluate the alterations that occur in the soil physical attributes in areas under different soil management systems for long periods in the Cerrado.

\section{Method}

\subsection{Experimental Area}

The experiment was conducted in experimental areas of the Instituto Federal do Triângulo Mineiro (IFTM), Campus Uberaba, Minas Gerais state, Brazil, between March 2017 and March 2018. The management systems studied are described in Table 1.

Table 1. Description of the areas of each soil management system studied

\begin{tabular}{|c|c|}
\hline Areas & Characteristics \\
\hline NTS5 & $\begin{array}{l}\text { Total area: } 0.21 \text { ha; height: } 797 \mathrm{~m} \text { asl; location: } 19^{\circ} 39^{\prime} 22.69^{\prime \prime} \mathrm{S}, 47^{\circ} 57^{\prime} 25.86^{\prime \prime} \mathrm{E} \text {; } \\
\text { area in the process of transition to a stabilised no-tillage system. }\end{array}$ \\
\hline NTS17 & $\begin{array}{l}\text { Total area: } 0.21 \text { ha; height: } 798 \mathrm{~m} \text { asl; location: } 19^{\circ} 39^{\prime} 21.81^{\prime \prime} \mathrm{S}, 47^{\circ} 57^{\prime} 26.82^{\prime \prime} \mathrm{E} \text {; } \\
\text { area in the process of consolidation of a stabilised no-tillage system. }\end{array}$ \\
\hline CTS20 & $\begin{array}{l}\text { Total area: } 6.75 \text { ha; height: } 819 \mathrm{~m} \text { asl } \text { location: } 19^{\circ} 39^{\prime} 10.17^{\prime \prime} \mathrm{S}, 47^{\circ} 58^{\prime} 15.65^{\prime \prime} \mathrm{E} \text {; } \\
\text { irrigated area (irrigated) and conducted under conventional tillage system. }\end{array}$ \\
\hline NA & $\begin{array}{l}\text { Total area: } 10.20 \text { ha; height: } 790 \mathrm{~m} \text { asl ; location: } 19^{\circ} 39^{\prime} 38.89^{\prime \prime} \mathrm{S}, 47^{\circ} 57^{\prime} 45.06^{\prime \prime} \mathrm{E} \text {. } \\
\text { area of preservation, without anthropic interference. }\end{array}$ \\
\hline
\end{tabular}

Note. NTS5: five-years-old no-tillage cropping system; NTS17: seventeen-years-old no-tillage cropping system; CTS20: twenty-years-old conventional tillage system; NA: native area (Cerrado biome typical area); asl: above sea level.

The climate of the region is classified as Aw, tropical hot, according to Beck et al. (2018), with the hot rainy summer and dry cold winter, with average annual rainfall, temperature and air relative humidity of $1600 \mathrm{~mm}$, $22.6{ }^{\circ} \mathrm{C}$ and $68 \%$, respectively. However, during the evaluation period was recorded $1995.3 \mathrm{~mm}$ of cumulative rainfall (INMET, 2018).

The soil of the experimental areas was classified as Dystrophic Red Latosol (LVd) (Santos et al., 2013), medium sandy texture. The cropping areas were cultivated under the conventional tillage system until the implantation of the no-tillage system (NTS), 5 and 17 years before this study. The soil texture between 0 and $0.4 \mathrm{~m}$ soil depth was about 220,720 and $60 \mathrm{~g} \mathrm{~kg}^{-1}$ of clay, sand and silt, respectively. 


\subsection{Experimental Design and Installation}

The most appropriated experimental design for this study was the completely randomized parcel distribution. Four systems were then tested: 1) no-tillage system implanted 5 years before (NTS5), 2) no-tillage system implanted 17 years before (NTS17), 3) consolidated conventional tillage system for twenty years (CTS20), and 4) native area (NA), characterized by Cerrado vegetation, in area without anthropic interference. Soil sample collections happened at 0-0.1, 0.1-0.2, 0.2-0.3 and 0.3-0.4 m, and replicated five times in each area. The NTS5, NTS17 and CTS20 systems went to several cycles of cover crops (e.g., pearl millet, sunn hemp), rotated with annual crops (e.g., corn, soybeans, beans and sorghum). In the NTS5 and NTS17 areas, the sample collection occurred after soybean crop, and after maize in the CTS20 area.

The NTS5 area received one plowing and two harrowings (deep plowing and levelling) before its implantation. The NTS17 area received one subsoiling activity 12 months after its installation with a ripper equipped with a straw cutting disc and a ripper roll. This same equipment was used in the area of CTS20, in 2015, followed by one plowing activity, two harrowings, and one levelling grade preceding sowing.

In general, the fertilization applied to maize production was $400 \mathrm{~kg} \mathrm{ha}^{-1}$ of 8-28-16 (NPK) at sowing, plus 140 and $80 \mathrm{~kg} \mathrm{ha}^{-1}$ of $\mathrm{K}$ top-dressed at 20 and 40 days after sowing, respectively. To the soybean production, seeds were inoculated, and $200 \mathrm{~kg} \mathrm{ha}^{-1}$ of $0-20^{-1} 5$ (NPK) plus $2.5 \% \mathrm{Zn}$ plus $2.5 \%$ of Mn, was applied, corresponding to $40 \mathrm{~kg}$ of $\mathrm{P}_{2} \mathrm{O}_{5}, 60 \mathrm{~kg}$ of $\mathrm{K}_{2} \mathrm{O}, 5 \mathrm{~kg}$ of $\mathrm{Zn}$, and $5 \mathrm{~kg}$ of Mn per hectare.

\subsection{Evaluations}

The evaluation of soil mechanical resistance to root penetration (RP) was conducted with the impact of penetrometer model Planalsucar/IAA, with a $30^{\circ}$ tip angle (Stolf et al., 2014) at soil depths of 0-0.1, 0.1-0.2, $0.2-0.3$ and $0.3-0.4 \mathrm{~m}$. The field data were registered in numbers of impacts $(\mathrm{n})$, then processed in the equation: $\mathrm{R}\left(\mathrm{kgf} \mathrm{cm}^{-2}\right)=5.6+6.98 \cdot \mathrm{n}$ (Sene et al., 1985), and multiplied by 0.098 to reach MPa unit (Arshad et al., 1996).

In the experimental areas, trenches were opened to collect two undisturbed samples with the aid of volumetric rings $(48 \mathrm{~mm}$ in diameter by $53 \mathrm{~mm}$ height), with the Uhland treaty, at $0-0.1,0.1-0.2,0.2-0.3,0.3-0.4 \mathrm{~m}$ to determine soil density (SD). These samples were previously water soaked for $24 \mathrm{~h}$, suctioned $(0.6 \mathrm{~m}$ water column height), and dried at $105{ }^{\circ} \mathrm{C}$ for 24 hours; macroporosity (Ma), total porosity (TP), microporosity (Mi) and volumetric moisture (VM) were then defined according to Teixeira et al. (2017).

The stability of water-stable aggregates was evaluated by the method described by Kemper and Chepil (1965), which consists of duplicated air-dried soil samples $(50 \mathrm{~g})$ composed of aggregates of diameter between 9.51 to $4.76 \mathrm{~mm}$. The samples were moistened by capillarity during 12 hours before transference to sieves of 4, 2, 1, 0.5, 0.25 and $0.13 \mathrm{~mm}$ grade. The set of soil samples and sieves was shaken in water with vertical oscillation (15 minutes). After shaking, the contents of each sieve was transferred to weighed metal containers and dried for 24 hours at $105^{\circ} \mathrm{C}$ to determine soil aggregate mass.

The weighted average diameter (WAD) (Equation 1) was calculated with the soil aggregate masses. A superior WAD corresponds to a superior percentage of large aggregates retained on the sieves with larger meshes; therefore, the presence of greate size soil aggregates, or superior WAD, may directly reflect soil resistance to erosion. The geometric average diameter (GAD) of soil aggregates represents an estimate of the size of the aggregates of large occurrence and can be estimated by Equation 2 .

The aggregate stability index (ASI) (Equation 3) is a measure of the total soil aggregation and does not consider the aggregate distribution per class; therefore, the higher the number of aggregates, $<0.25 \mathrm{~mm}$, the lesser will be the ASI.

These indices of soil aggregation were calculated in the following way:

$$
\text { WAD (weighted average diameter, } \mathrm{mm})=\sum(\mathrm{xi} \times \text { wi) }
$$

where, 'xi' is the average diameter of classes $(\mathrm{mm})$; and wi, the proportion of each class in relation to the total (Wendling et al., 2005);

$$
\text { GAD (geometric average diameter, } \mathrm{mm})=\exp \left\{\sum[(\ln [\mathrm{xi}] \cdot[\mathrm{wi}])] / \sum[\mathrm{wi}]\right\}
$$

where, 'In[xi]' is the natural logarithm of the average diameter of classes; and 'wi' is the aggregate weight (g) retained in each sieve;

$$
\text { ASI (aggregate stability index, \%) }=[(\mathrm{W}-\mathrm{wp}<0.25) /(\mathrm{W})] \times 100
$$

where, ' $\mathrm{W}$ ' is the sample weight; and, 'wp $<0.25$ ' corresponds to the weight (grams) of aggregates in the class “<0.25 mm" (Demarchi et al., 2011). 
To compare the values of RP, SD, VM, Ma, Mi, TP, WAD, and ASI from areas of different management systems (CTS20, NTS5 and NTS17) and the results found in the NA, the index of sensitivity (IS), proposed by Bolinder et al. (1999) was used. This index estimates the intensity of the changes in soil physical attributes as a function of the management system used. This index was calculated according to the equation:

$$
\text { IS }=\text { as/ac }
$$

where, where 'IS' is the index of sensitivity; "as", the value of the variables (RP, SD, VM, Ma, Mi, TP, WAD, and ASI) of each system (SPC20, NT5 and NT17); and "ac" is the value of the same variables obtained in the native area (Cerrado biome). The closer to the unit is the 'Is', the lower will be the change caused by the management system used; if less than, equal to or greater than one (1), it is understood that worsened, maintained, or improved the soil physical attributes evaluated, respectively.

\subsection{Statistical Analysis}

The results were submitted to the ANAVA presumptions: normality of the distribution of errors (Lilliefors test) and homogeneity of variances of the errors (Cochran test), both at $\mathrm{p}>0.01$. After presumptions attendance, the results were submitted to the ANOVA ( $F$ test) and the mean values compared by the Tukey test at $5 \%$ probability $(\mathrm{p}<0.05)$.

\section{Results and Discussion}

\subsection{Soil Resistance to Penetration, Density and Humidity}

The resistance to root penetration and soil bulk density presented results that indicate an initial phase of the soil compaction occurring in depth between 0.2 and $0.3 \mathrm{~m}$ in the area cultivated under conventional tillage system for 20 years (CTS20). However, areas under the no-tillage system for five (NTS5) and seventeen years (SPD17), this soil compacted layer occurred in the most superficial layer $(0-0.1 \mathrm{~m})$, while in the native Cerrado area (NA), no soil impediment to root growth was observed (Table 2). The results found can be due to the soil preparation done in the NTS5 area, before system implantation, to the subsoiling activity in the NTS17 area (12 months after its implantation), and in the CTS20 area, in 2015 (Torres et al., 2015b).

Table 2. Soil resistance to root penetration (RP), bulk density (SD) and volumetric moisture (VM) in soil management systems and depths

\begin{tabular}{|c|c|c|c|c|}
\hline \multirow{2}{*}{ Soil depth $(\mathrm{m})$} & \multicolumn{4}{|c|}{ Soil management system } \\
\hline & CTS20 & NTS5 & NTS17 & NA \\
\hline & \multicolumn{4}{|c|}{ - } \\
\hline $0-0.1$ & $1.90 \mathrm{bB}^{*}$ & $3.11 \mathrm{aA}$ & $2.59 \mathrm{aA}$ & $1.32 \mathrm{cA}$ \\
\hline $0.1-0.2$ & $2.38 \mathrm{bA}$ & $2.66 \mathrm{aB}$ & $2.42 \mathrm{bA}$ & $1.42 \mathrm{cA}$ \\
\hline $0.2-0.3$ & $2.52 \mathrm{aA}$ & $2.52 \mathrm{aB}$ & $2.21 \mathrm{aA}$ & $1.56 \mathrm{bA}$ \\
\hline $0.3-0.4$ & $2.01 \mathrm{aA}$ & $2.14 \mathrm{aC}$ & $1.87 \mathrm{aB}$ & $1.39 \mathrm{bA}$ \\
\hline \multirow[t]{2}{*}{ CV $(\%)$} & \multicolumn{4}{|l|}{12.69} \\
\hline & \multicolumn{4}{|c|}{ SD $\left(\mathrm{kg} \mathrm{dm}^{-3}\right)$} \\
\hline $0-0.1$ & $1.67 \mathrm{aA}$ & $1.62 \mathrm{aA}$ & $1.71 \mathrm{aA}$ & $1.23 \mathrm{aA}$ \\
\hline $0.1-0.2$ & $1.68 \mathrm{aA}$ & $1.47 \mathrm{bB}$ & $1.47 \mathrm{bB}$ & $1.14 \mathrm{cA}$ \\
\hline $0.2-0.3$ & $1.75 \mathrm{aA}$ & $1.59 \mathrm{aA}$ & $1.61 \mathrm{aA}$ & $1.26 \mathrm{bA}$ \\
\hline $0.3-0.4$ & $1.66 \mathrm{aA}$ & $1.57 \mathrm{aA}$ & $1.57 \mathrm{aA}$ & $1.25 \mathrm{bA}$ \\
\hline \multirow[t]{2}{*}{ CV $(\%)$} & \multicolumn{4}{|l|}{5.30} \\
\hline & \multicolumn{4}{|l|}{--י--י } \\
\hline $0-0.1$ & $0.15 \mathrm{cA}$ & $0.18 \mathrm{cA}$ & $0.21 \mathrm{bA}$ & $0.28 \mathrm{aB}$ \\
\hline $0.1-0.2$ & $0.15 \mathrm{cA}$ & $0.18 \mathrm{cA}$ & $0.21 \mathrm{bA}$ & $0.28 \mathrm{aB}$ \\
\hline $0.2-0.3$ & $0.16 \mathrm{cA}$ & $0.18 \mathrm{cA}$ & $0.21 \mathrm{bA}$ & $0.28 \mathrm{aB}$ \\
\hline $0.3-0.4$ & $0.15 \mathrm{cA}$ & $0.19 \mathrm{bA}$ & $0.20 \mathrm{bA}$ & $0.33 \mathrm{aA}$ \\
\hline $\mathrm{CV}(\%)$ & 9.78 & & & \\
\hline
\end{tabular}

Note. $*$ = Averages followed by the same letter-lowercase letters in lines, comparing soil management systems, and uppercase letters in columns, comparing soil depths - do not differ by the Tukey test $(p<0.05)$. NTS5: five-years-old no-tillage cropping system; NTS17: seventeen-years-old no-tillage cropping system; CTS20: twenty-years-old conventional tillage system; NA: native area (Cerrado biome typical area). CV (\%) $=$ coefficient of variation. 
The RP results ranged from 1.32 to $3.11 \mathrm{Mpa}$, which still bellow or within the range of 2 to 4 Mpa proposed as critical to root development of annual crops (Arshad et al., 1996; Suzuki et al., 2007; Silva et al., 2008); however, these effects are more harmful to plants when soil presents low humidity (Tavares Filho \& Tessier, 2009), as it occurred in the present study, where de volumetric moisture ranged between 0.15 and $0.21 \mathrm{~cm}^{3} \mathrm{~cm}^{-3}$, in areas under NTS5, NT17 and SPC20, which is well below the field capacity considered ideal by Arshad et al. (1996).

According to Girardello et al. (2014), soils with high RP resistance restrict root development, producing narrow root systems, branched and with worse distribution in the soil profile. This situation undermines the efficiency of fertilisers, water and limits crop productivity. Freddi et al. (2006) highlight that the RP resistance usually presents a greater relationship with crop productivity than with other physical attributes, such as the SD and TP.

The soil physical attributes in an area of 23 years of NTS indicated that superior SD occurred at a soil depth of 0.05-0.1 m (Hickmann et al., 2012); however, Reichert et al. (2009) reported that the highest indices of SD and $\mathrm{RP}$ resistance occurred between 0.08 and $0.15 \mathrm{~m}$ soil depth, and concluded that the SD increase interfered with the root development, reduced soil aeration and altered soil water dynamics and increased. The effect of soil compression on soybean productivity in a Dystrophic Red Latosol was studied by Beutler et al. (2006). The authors determined that the RP resistance ranged from 2.24 to $2.97 \mathrm{MPa}$, and causes significant decreases to soybean production; however, the reductions varied among soybean cultivars.

The SD observed in this study ranged from 1.66 to $1.75 \mathrm{~kg} \mathrm{dm}^{-3}$ in SPD20 area; 1.47 to $1.62 \mathrm{~kg} \mathrm{dm}^{-3}$ in SPD5 area, and 1.47 to $1.71 \mathrm{~kg} \mathrm{dm}^{-3}$ for the SPD17; however, the soil density observed was similar among soil depths in the CTS20, and the lowest in the soil depth of 0.1-0.2 m of the other areas (NTS5, NTS17 and NA) (Table 1). The critical SD value established for root development is $1.55 \mathrm{~kg} \mathrm{dm}^{-3}$ for soils with clay content ranging between 200 and $550 \mathrm{~g} \mathrm{~kg}^{-1}$ (Reinert et al., 2008), or $1.60 \mathrm{~kg} \mathrm{dm}^{-3}$, as proposed by Silva and Rosolem (2001). These critical SD values indicate the occurrence of soil layers with some level of resistance to full root development in the NTS5, NTS17 and CTS20 cropping systems. In the Cerrado NA area, the SD ranged from 1.14 to $1.26 \mathrm{~kg} \mathrm{dm}^{-3}$, indicating no physical impediment to the development of root systems.

The same soil attributes in the NTS17 experimental area were evaluated by Torres et al. (2015a) when the system had 12 years of implantation (NTS12) under different cover crops. The authors found that the SD was about 1.58 , 1.56 and $1.56 \mathrm{~kg} \mathrm{dm}^{-3}$ for the $0-0.1,0.1-0.2$ and $0.2-0.3 \mathrm{~m}$ soil depth, respectively. The results found in the present study (Table 2), five years after the study conducted by Torres et al. (2015a), indicate an increase of the SD of the $0-0.1 \mathrm{~m}\left(1.71 \mathrm{~kg} \mathrm{dm}^{-3}\right)$ and $0.2-0.3 \mathrm{~m}$ soil layer $\left(1.61 \mathrm{~kg} \mathrm{dm}^{-3}\right)$, and a decrease of this attribute in the 0.1-0.2 m soil layer $\left(1.47 \mathrm{~kg} \mathrm{dm}^{-3}\right)$ over the years. The high increment of SD in the superficial soil layer, from 12 to 17 years of NTS, possibly indicates the effect of traffic on the area over time; however, the soil density in the sub-superficial soil layer (0.1-0.2 m) decreased, meaning that over time this soil layer reaches a SD condition that facilitates roots development (Reinert et al., 2008; Silva \& Rosolem, 2001).

\subsection{Soil Macroporosity, Microporosity and Total Porosity}

The soil macroporosity, microporosity and total porosity of the NA Cerrado area were similar or superior $(\mathrm{p}<$ 0.05 ) to the results found in the areas of the cropping systems (CTS20, NTS5 and NTS17). No microporosity differences among soil depths were observed for any of the studied areas $(\mathrm{p}>0.05)$. The total of soil pores (TP) was superior in the most superficial soil layer $(0-0.1 \mathrm{~m})$ of the NTS5 and NA areas and reduced with soil depth (Table 3). 
Table 3. Soil macroporosity (Ma), microporosity (Mi) and total porosity (TP) in soil management systems and depths

\begin{tabular}{lllll}
\hline \multirow{2}{*}{ Soil depth $(\mathrm{m})$} & \multicolumn{4}{c}{ Soil management system } \\
\cline { 2 - 5 } & CTS20 & NTS5 & NTS17 & NA \\
\hline Ma & & & \\
$0-1$ & $11.94 \mathrm{bA}$ & $20.81 \mathrm{aA}$ & $15.75 \mathrm{bA}$ & $23.97 \mathrm{aA}$ \\
$0.1-0.2$ & $11.10 \mathrm{bA}$ & $14.96 \mathrm{bA}$ & $13.33 \mathrm{bA}$ & $19.75 \mathrm{aB}$ \\
$0.2-0.3$ & $15.78 \mathrm{aA}$ & $14.43 \mathrm{aA}$ & $13.65 \mathrm{aA}$ & $15.66 \mathrm{aB}$ \\
$0.3-0.4$ & $14.79 \mathrm{aA}$ & $14.68 \mathrm{aA}$ & $14.66 \mathrm{aA}$ & $16.54 \mathrm{aB}$ \\
$\mathrm{CV}(\%)$ & 26.49 & & & \\
\hline$M i$ & & & \\
$0-0.1$ & $24.77 \mathrm{bA}$ & $24.87 \mathrm{bA}$ & $27.77 \mathrm{bA}$ & $32.18 \mathrm{aA}$ \\
$0.1-0.2$ & $25.24 \mathrm{bA}$ & $25.02 \mathrm{bA}$ & $25.69 \mathrm{bA}$ & $32.84 \mathrm{aA}$ \\
$0.2-0.3$ & $23.29 \mathrm{bA}$ & $26.07 \mathrm{bA}$ & $26.58 \mathrm{bA}$ & $35.21 \mathrm{aA}$ \\
$0.3-0.4$ & $23.71 \mathrm{bA}$ & $27.00 \mathrm{bA}$ & $26.46 \mathrm{bA}$ & $33.26 \mathrm{aA}$ \\
$\mathrm{CV}(\%)$ & 9.90 & & & \\
\hline$T P$ & & & & \\
$0-0.1$ & $36.72 \mathrm{cA}$ & $45.68 \mathrm{bA}$ & $43.52 \mathrm{bA}$ & $56.15 \mathrm{aA}$ \\
$0.1-0.2$ & $36.34 \mathrm{bA}$ & $39.98 \mathrm{bB}$ & $39.02 \mathrm{bA}$ & $52.59 \mathrm{aB}$ \\
$0.2-0.3$ & $39.08 \mathrm{bA}$ & $40.51 \mathrm{bB}$ & $40.23 \mathrm{bA}$ & $50.87 \mathrm{aB}$ \\
$0.3-0.4$ & $38.50 \mathrm{bA}$ & $41.69 \mathrm{bB}$ & $41.12 \mathrm{bA}$ & $49.81 \mathrm{aB}$ \\
$\mathrm{CV}(\%)$ & 6.70 & & \\
\hline
\end{tabular}

Note. $*$ = Averages followed by the same letter-lowercase letters in lines, comparing soil management systems, and uppercase letters in columns, comparing soil depths - do not differ by the Tukey test $(p<0.05)$. NTS5: five-years-old no-tillage cropping system; NTS17: seventeen-years-old no-tillage cropping system; CTS20: twenty-years-old conventional tillage system; NA: native area (Cerrado biome typical area). CV (\%) = coefficient of variation.

In the $0-0.1 \mathrm{~m}$ soil layer of the NTS17 system, 35 and $65 \%$ of Ma and Mi were found, respectively. These values are very close to the ideal proportions ( $34 \%$ of Ma, $66 \%$ of Mi) indicated by Kiehl (1979), and close to the results found in the Cerrado NA- $37 \%$ of Ma and $63 \%$ of Mi. The soil from the NTS5 presented 17 and $83 \%$ of $\mathrm{Ma}$ and Mi, respectively, far from the ideal for the root development (Kiehl, 1979). The lowest TP value found was in the $0-0.1 \mathrm{~m}$ soil layer of the SPC20 system, about $20 \%$ lower than the MA, and 9\% lower than the NTS5 and NTS17.

Although the low Ma values observed in all treatments, at no point has reached the limit value of $10 \%$, which represents the critical limit considered to hinder root growth of annual crops (Kiehl, 1979). Michelon et al. (2007) also highlighted that the minimum value of $10 \%$ of macropores is appropriate for liquid and gaseous exchanges between the external environment and the soil environment, which are considered critical for the root development of most cultures. The process of soil compaction reduces the macropore abundance-affecting liquid and gaseous exchanges - and increase the presence of micropores. This situation highlights the effect of traffic during crop management, which significantly reduces the percentage of macropores present in soil (Viana et al., 2011).

According to Lago et al. (2012), it is common for soils to present high Mi and low Ma and TP in the superficial layer after three to four years of NTS implantation. The authors concluded that the natural soil arrangement and the pressure caused by the transit of heavy agricultural machines as responsible for the changes observed. Such results were not observed in the present study - the microporosity and the total of soil pores were above the soil macroporosity. This situation is justified by the soil compaction that occurs in the most superficial layers in the areas in NTS5 and NTS17. Hernani and Salton (2009) also observed that soil density and soil total porosity in the superficial soil layers increased under different management systems of 16 years-old. In general, soils with great SD present decreased TP, reduction of water permeability and the infiltration of water, destruction of aggregates and increase RP, compromising the soil physical quality (Pezarico et al., 2013). 
The Ma/TP relationship significantly increase $(\mathrm{p}<0.05)$ at the $0-0.1 \mathrm{~m}$ soil depth of the NTS5 area compared to the NTS17, CTS20 and Cerrado NA. Even so, in all areas-except in the 0-0.3 m soil depth in the CTS20 cropping system - the values were above $0.33 \mathrm{dm}^{-3} \mathrm{dm}^{-3}$ (Table 4). These values are considered ideal since they are above $1 / 3$ of the TP (Taylor $\&$ Aschcroft, 1972).

Table 4. Soil macroporosity and total porosity relation (Ma/TP) in soil management systems and depths

\begin{tabular}{lllll}
\hline \multirow{2}{*}{ Soil depth (m) } & \multicolumn{4}{c}{$\mathrm{Ma} / \mathrm{TP}$} \\
\cline { 2 - 5 } & CTS20 & CTS20 & CTS20 & CTS20 \\
\hline $0-0.1$ & $0.32 \mathrm{aA}^{*}$ & $0.45 \mathrm{aA}$ & $0.36 \mathrm{aA}$ & $0.43 \mathrm{aA}$ \\
$0.1-0.2$ & $0.30 \mathrm{aA}$ & $0.37 \mathrm{aB}$ & $0.34 \mathrm{aA}$ & $0.37 \mathrm{aA}$ \\
$0.2-0.3$ & $0.31 \mathrm{aA}$ & $0.35 \mathrm{aB}$ & $0.33 \mathrm{aA}$ & $0.40 \mathrm{aA}$ \\
$0.3-0.4$ & $0.33 \mathrm{aA}$ & $0.35 \mathrm{aB}$ & $0.35 \mathrm{aA}$ & $0.38 \mathrm{aA}$ \\
\hline CV $(\%)$ & 22.43 & & & \\
\hline
\end{tabular}

Note. $*$ = Averages followed by the same letter-lowercase letters in lines, comparing soil management systems, and uppercase letters in columns, comparing soil depths - do not differ by the Tukey test $(p<0.05)$. NTS5: five-years-old no-tillage cropping system; NTS17: seventeen-years-old no-tillage cropping system; CTS20: twenty-years-old conventional tillage system; NA: native area (Cerrado biome typical area). CV (\%) = coefficient of variation.

To Bertol et al. (2004), the $0.33 \mathrm{dm}^{-3} \mathrm{dm}^{-3}$ value is limiting to root development. Values bellow $0.33 \mathrm{dm}^{-3} \mathrm{dm}^{-3}$ reduces the rate of gas diffusion in the soil and hinders the drainage of water from rains. In their study, values above $0.4,0.2$ and $0.2 \mathrm{dm}^{-3} \mathrm{dm}^{-3}$ in the $0.05 \mathrm{~m}$ depth, and minimum values of $0.07,0.1$ and $0.15 \mathrm{dm}^{-3} \mathrm{dm}^{-3}$ in the 0.05 to $0.30 \mathrm{~m}$ soil depth, for conventional tillage, NTS and NA, respectively.

\subsection{Soil Aggregate Stability}

After the determination of the aggregate stability, the aggregate stability index (ASI) in water, the weighted average diameter (WAD) and the mean geometric diameter (MGD) were calculated, and were superior $(\mathrm{p}<0.05)$ in the superficial layer $(0-0.1 \mathrm{~m})$, decreasing with soil depth in the studied areas (Table 5). The mean values of WAD, GAD and IEA followed the sequence: NA $>$ NTS17 > NTS5 > CTS20, demonstrating the importance of the crop residues (litter and roots), regularly available in the Cerrado NA area. These crop residues can alter soil structural quality as the crop seasons succeed (Lima et al., 2013). 
Table 5. Weighted average diameter (WAD), geometric average diameter (GAD) and the aggregate stability index (ASI) in soil management systems and depths

\begin{tabular}{lllll}
\hline \multirow{2}{*}{ Soil depth (m) } & \multicolumn{4}{c}{ Soil management system } \\
\cline { 2 - 5 } CTS20 & CTS20 & CTS20 & CTS20 \\
\hline $0-0.1$ & $2.06 \mathrm{cA}^{*}$ & $3.61 \mathrm{bA}$ & $3.72 \mathrm{bA}$ & $4.61 \mathrm{aA}$ \\
$0.1-0.2$ & $0.66 \mathrm{~dB}$ & $1.47 \mathrm{cB}$ & $2.42 \mathrm{bB}$ & $3.84 \mathrm{aB}$ \\
$0.2-0.3$ & $0.75 \mathrm{cB}$ & $1.56 \mathrm{bB}$ & $2.17 \mathrm{bB}$ & $3.80 \mathrm{aB}$ \\
$0.3-0.4$ & $0.67 \mathrm{cB}$ & $1.19 \mathrm{cB}$ & $2.49 \mathrm{bB}$ & $3.82 \mathrm{aB}$ \\
\hline $\mathrm{CV}(\%)$ & 21.00 & & & \\
\hline$G A D(m m)$ & & & \\
$0-0.1$ & $0.97 \mathrm{bA}$ & $2.39 \mathrm{aA}$ & $2.52 \mathrm{aA}$ & $2.33 \mathrm{aA}$ \\
$0.1-0.2$ & $0.38 \mathrm{bA}$ & $0.72 \mathrm{bB}$ & $1.32 \mathrm{aB}$ & $1.72 \mathrm{aA}$ \\
$0.2-0.3$ & $0.45 \mathrm{bA}$ & $0.81 \mathrm{bB}$ & $1.15 \mathrm{bB}$ & $1.95 \mathrm{aA}$ \\
$0.3-0.4$ & $0.39 \mathrm{bA}$ & $0.77 \mathrm{bB}$ & $1.31 \mathrm{aB}$ & $1.77 \mathrm{aA}$ \\
\hline $\mathrm{CV}(\%)$ & 27.30 & & & \\
\hline$A S I(\%)$ & & & \\
$0-0.1$ & $81.57 \mathrm{cB}$ & $85.54 \mathrm{bB}$ & $85.10 \mathrm{bB}$ & $91.75 \mathrm{aB}$ \\
$0.1-0.2$ & $84.65 \mathrm{dA}$ & $94.12 \mathrm{bA}$ & $90.30 \mathrm{cA}$ & $97.34 \mathrm{aA}$ \\
$0.2-0.3$ & $84.79 \mathrm{cA}$ & $93.77 \mathrm{bA}$ & $91.31 \mathrm{bA}$ & $96.98 \mathrm{aA}$ \\
$0.3-0.4$ & $84.70 \mathrm{cA}$ & $95.24 \mathrm{aA}$ & $90.02 \mathrm{bA}$ & $97.32 \mathrm{aA}$ \\
$\mathrm{CV}(\%)$ & 2.26 & & \\
\hline
\end{tabular}

Note. $*=$ Averages followed by the same letter-lowercase letters in lines, comparing soil management systems, and uppercase letters in columns, comparing soil depths - do not differ by the Tukey test $(p<0.05)$. NTS5: five-years-old no-tillage cropping system; NTS17: seventeen-years-old no-tillage cropping system; CTS20: twenty-years-old conventional tillage system; NA: native area (Cerrado biome typical area). CV (\%) $=$ coefficient of variation.

The distribution of soil aggregates in areas of pasture, cropland and forest in the Southern region of Brazil indicated that a considerable proportion of the water-stable aggregates is in class 8 to $2 \mathrm{~mm}$, especially in areas cultivated with Poaceae plant species (grasses), when compared to a native area (Ferreira et al., 2007). The authors justified this pattern as a consequence of the vigorous root system of the grasses species, which is dense, well-distributed and produces great amounts of aggregating exudates in the soil.

The comparison among NTS, integrated crop-livestock (ICL) and native forest indicated that, regardless of the soil depth, the native forest presented the highest values of WAD, GAD and ASI (Loss et al., 2011). The authors explained that this result was due to the larger inflow of plant material in the area of native forest. However, in the areas under NTS and CTS the soil compaction problems may occur due to the intensive traffic of heavy agricultural machines and implements, causing changes to the soil structural arrangements of volume and pore size, affecting soil water and gases diffusion and root development (Ralisch et al., 2008).

The low values of WAD, GAD and ASI observed for the 0-0.1, 0.1-0.2, 0.2-0.3 and 0.30-0.40 m soil layers of the CTS20 can be explained by the intensive soil revolving before plant cropping. Similar results were found by Loss et al. (2009) when comparing CTS, NTS, agroforestry systems and combined crops, found that the lowest values of WAD and GAD in the CTS, while Pinheiro et al. (2004) found lower changes in soil aggregation in areas of cultivation of horticultural crops under NTS.

According to Silveira et al. (2011), residues of the Poaceae plant species present a positive effect on soil aggregation due to their high content of lignin. The lignin increases the content of carboxylic acids and humic acids in the soil substrate, improving the stability of aggregates and soil structure; additionally, the root system of Poaceae plants is highly dense, aggregating soil particles by the constant water absorption from soil and periodic renewal of the root system.

The accumulation of plant residues on the soil surface and consequent soil organic matter uprise indicates that this soil might be protected against the impact of raindrops and sudden changes of soil moisture. Also, the 
deposition of organic matter on the soil accelerates the soil microbial activity which produces more organic substances that assist in the formation and stabilization of soil aggregates (Loss et al., 2012).

The index of sensitivity (IS) enables to assess the changes caused by cropping systems concerning the native area (NA). The RP, SD and ASI results were significantly higher in the CTS20, NTS5 and NTS17, when compared to the NA soil (Table 6). These indicators show that there is a densification of the soil particles in the surface and subsurface soil layers. Even with increased ASI, the soil is still losing quality because it is experiencing an adverse change in the dynamics of air and water, which hinders plant root development (Mcphee et al., 2015; Torres et al., 2015a; Moraes et al., 2016).

Table 6. Index of sensitivity (IS) (average results) comparing NTS5 (five-years-old no-tillage cropping system), NTS17 (seventeen-years-old no-tillage cropping system), and CTS20 (twenty-years-old conventional tillage system) systems to the native area (NA, Cerrado biome typical area)

\begin{tabular}{|c|c|c|c|c|c|c|c|c|c|}
\hline \multirow{2}{*}{ System } & \multicolumn{9}{|c|}{ Soil physical attributes } \\
\hline & RP & SD & $\mathrm{VM}$ & $\mathrm{Ma}$ & $\mathrm{Mi}$ & $\mathrm{TP}$ & WAD & GAD & ASI \\
\hline \multicolumn{10}{|c|}{ Soil management system (SM) } \\
\hline CTS20 & $1.55 \mathrm{~b}$ & $1.38 \mathrm{a}$ & $0.73 \mathrm{~b}$ & $0.74 \mathrm{~b}$ & $0.73 \mathrm{~b}$ & $0.72 \mathrm{c}$ & $0.25 \mathrm{~d}$ & $0.31 \mathrm{c}$ & $1.14 \mathrm{a}$ \\
\hline NTS5 & $1.85 \mathrm{a}$ & $1.29 \mathrm{~b}$ & $0.53 \mathrm{~d}$ & $0.86 \mathrm{~b}$ & $0.78 \mathrm{~b}$ & $0.80 \mathrm{~b}$ & $0.47 \mathrm{c}$ & $0.66 \mathrm{~b}$ & $1.10 \mathrm{~b}$ \\
\hline NTS17 & $1.62 \mathrm{~b}$ & $1.32 \mathrm{~b}$ & $0.63 \mathrm{c}$ & $0.79 \mathrm{~b}$ & $0.80 \mathrm{~b}$ & $0.79 \mathrm{~b}$ & $0.68 \mathrm{~b}$ & $0.91 \mathrm{a}$ & $1.06 \mathrm{c}$ \\
\hline NA & $1.00 \mathrm{c}$ & $1.00 \mathrm{c}$ & $1.00 \mathrm{a}$ & $1.00 \mathrm{a}$ & $1.00 \mathrm{a}$ & $1.00 \mathrm{a}$ & $1.00 \mathrm{a}$ & $1.00 \mathrm{a}$ & $1.00 \mathrm{~d}$ \\
\hline$F$ test & $41.15^{* *}$ & $51.67 * *$ & $103.56^{* *}$ & $4.27 * *$ & $29.27 * *$ & $64.57 * *$ & $167.84 * *$ & $15.83 * *$ & $71.58 * *$ \\
\hline \multicolumn{10}{|c|}{ Soil depth $(\overline{S D})$} \\
\hline $0-0.1$ & $1.62 \mathrm{a}$ & $1.26 \mathrm{a}$ & $0.74 \mathrm{a}$ & $0.76 \mathrm{~b}$ & $0.86 \mathrm{a}$ & $0.81 \mathrm{a}$ & $0.76 \mathrm{a}$ & $0.99 \mathrm{a}$ & $1.05 \mathrm{~b}$ \\
\hline $0.1-0.2$ & $1.65 \mathrm{a}$ & $1.26 \mathrm{a}$ & $0.74 \mathrm{a}$ & $0.75 \mathrm{~b}$ & $0.83 \mathrm{a}$ & $0.80 \mathrm{a}$ & $0.55 \mathrm{~b}$ & $0.64 \mathrm{~b}$ & $1.08 \mathrm{a}$ \\
\hline $0.2-0.3$ & $1.42 \mathrm{~b}$ & $1.25 \mathrm{a}$ & $0.75 \mathrm{a}$ & $0.95 \mathrm{a}$ & $0.79 \mathrm{a}$ & $0.84 \mathrm{a}$ & $0.55 \mathrm{~b}$ & $0.61 \mathrm{~b}$ & $1.08 \mathrm{a}$ \\
\hline $0.3-0.4$ & $1.34 \mathrm{~b}$ & $1.24 \mathrm{a}$ & $0.66 \mathrm{a}$ & $0.92 \mathrm{a}$ & $0.83 \mathrm{a}$ & $0.86 \mathrm{a}$ & $0.54 \mathrm{~b}$ & $0.62 \mathrm{~b}$ & $1.08 \mathrm{a}$ \\
\hline$F$ test & $7.27 * *$ & $0.22^{\mathrm{ns}}$ & $4.59 * *$ & $3.90 *$ & $1.77^{\mathrm{ns}}$ & $3.46^{*}$ & $19.26 * *$ & $5.82 * *$ & $3.77 *$ \\
\hline \multicolumn{10}{|c|}{$S M \times S D$} \\
\hline$F$ teste & $2.75 *$ & $0.67^{\mathrm{ns}}$ & $0.64^{\mathrm{ns}}$ & $1.09^{\mathrm{ns}}$ & $0.55^{\mathrm{ns}}$ & $1.09^{\mathrm{ns}}$ & $3.58^{\mathrm{ns}}$ & $1.33^{\mathrm{ns}}$ & $1.02^{\mathrm{ns}}$ \\
\hline $\mathrm{CV}(\%)$ & 14.95 & 7.66 & 10.98 & 25.71 & 10.56 & 7.17 & 16.34 & 33.13 & 2.62 \\
\hline
\end{tabular}

Note. ${ }^{*}$ and $* *=$ significant at 0.05 and 0.01 , respectively. $\mathrm{ns}=$ non-significant. Averages followed by the same letter-lowercase letters in lines, comparing soil management systems, and uppercase letters in columns, comparing soil depths - do not differ by the Tukey test $(p<0.05)$.

RP: soil resistance to root penetration (Mpa); SD: soil bulk density $\left(\mathrm{kg} \mathrm{dm}^{-3}\right)$; VM: volumetric moisture $\left(\mathrm{cm}^{3}\right.$ $\mathrm{cm}^{-3}$ ); Ma: soil macroporosity (\%); Mi: soil microporosity (\%); TP: soil total porosity (\%); WAD: weighted average diameter $(\mathrm{mm})$; GAD: geometric average diameter (mm); ASI: aggregate stability index (\%).

$\mathrm{CV}(\%)=$ coefficient of variation .

The index of sensitivity of VM, Ma, Mi, TP, WAD, and GAD were lower than the observed in NA (1.0), which is the natural soil condition before any anthropic action. The agricultural activities in the cropping areas (SPC20, NTS5 and NTS17) caused negative changes to the soil structure, resulting in reduced total porosity, macroporosity, pore continuity, moisture and the size of the soil aggregates (Loss et al., 2012; Rossetti et al., 2012; Santos et al., 2014; Bai et al., 2018; Ordoñez-Morales et al., 2019). The main changes to the IS occur in the upper soil layer, for all physical attributes evaluated in CTS20, NTS5 and NTS17 areas when compared to the Cerrado NA. These changes might be due to the soil compaction of the upper soil layer in cropping systems (agricultural machinery traffic), even conservative soil managing system.

In the same region, Torres et al. (2011) reported the IS for the attributes SD, TP, Ma and Mi for different soil management systems: CTS, NTS, NA and pasture, at different soil depths. The authors observed that the most considerable variations of IS occurred for Ma in the CTS and pasture, and remained constant in the area under NTS; the SD, TP and Mi values changed little among all treatments.

The correlations between the indicators obtained in the soil management systems (CTS20, NTS5 and NTS17) and the NA, indicated that the SD was the attribute that directly correlated with all other attributes; positively with RP and ASI, and negatively with MV, Ma, Mi, TP, WAD and GAD (Table 7). 
Table 7. Pearson's correlation coefficient between the physical attributes evaluated in areas under different management systems and soil depths

\begin{tabular}{lllllllll}
\hline \multirow{2}{*}{ Indicator } & \multicolumn{2}{l}{ Soilphysicalattributes } & \multicolumn{2}{l}{} \\
\cline { 2 - 8 } & RP & SD & VM & Ma & Mi & TP & WAG & GAD \\
\hline SD & $0.47^{*}$ & - & - & - & - & - & - & - \\
VM & $-0.58^{*}$ & $-0.69^{*}$ & - & - & - & - & - & - \\
Ma & $-0.22^{\text {ns }}$ & $-0.49^{*}$ & $0.18^{\text {ns }}$ & - & - & - & - & - \\
Mi & $-0.51^{*}$ & $-0.73^{*}$ & $0.60^{*}$ & $-0.07^{\text {ns }}$ & - & - & - & - \\
TP & $-0.54^{*}$ & $-0.91^{*}$ & $0.57^{*}$ & $0.66^{*}$ & $0.68^{*}$ & - & - & - \\
WAD & $-0.41^{*}$ & $-0.66^{*}$ & $0.53^{*}$ & $0.25^{* *}$ & $0.65^{*}$ & $0.68^{*}$ & - & - \\
GAD & $-0.13^{\text {ns }}$ & $-0.31^{*}$ & $0.12^{\text {ns }}$ & $0.20^{\text {ns }}$ & $0.30^{* *}$ & $0.40^{*}$ & $0.80^{*}$ & - \\
ASI & $0.44^{*}$ & $0.63^{* *}$ & $-0.51^{*}$ & $-0.22^{* *}$ & $-0.62^{*}$ & $-0.65^{*}$ & $-0.96^{*}$ & $-0.78^{*}$ \\
\hline
\end{tabular}

Note. $*$ and $* *$ : Pearson coefficient significant at 0.01 and 0.05 , respectively.

RP: soil resistance to root penetration $(\mathrm{Mpa})$; $\mathrm{SD}$ : soil bulk density $\left(\mathrm{kg} \mathrm{dm}^{-3}\right)$; VM: volumetric moisture $\left(\mathrm{cm}^{3}\right.$ $\left.\mathrm{cm}^{-3}\right)$; Ma: soil macroporosity (\%); Mi: soil microporosity (\%); TP: soil total porosity (\%); WAD: weighted average diameter $(\mathrm{mm})$; GAD: geometric average diameter $(\mathrm{mm})$; ASI: aggregate stability index $(\%)$.

The correlations demonstrated that RP, SD and ASI increased simultaneously with the reduction of the VM, Ma, Mi, TP, WAD and GAD, demonstrating that the management system significantly changes the soil physical attributes. Similar results were evidenced by Torres et al. (2015b), in an area under no-tillage for 12 years in the same region.

According to Beutler et al. (2006), the correlations of SD with TP and Ma are generally negative, and with Mi the correlations are positive. These correlations occur due to the approximation of the soil particles due to the increase of the mechanical pressure exerted on the soil surface, which reduces the large-diameter pores and slightly increases the small-diameter pores.

The RP showed a positive correlation between SD and ASI, indicating that these attributes rise and fall simultaneously, and a negative correlation with VM, Ma, Mi, TP, WAD, and GAD, indicating that as the RP increases, the values observed in these attributes decrease. Hickmann et al. (2012) studying the physical attributes in an area 23 years NTS, similar soil results to those obtained in the present study for the majority of the variables analyzed.

\section{Conclusions}

The areas of conventional tillage and no-tillage presented great soil density in the most superficial soil layer, which was not sufficient to cause resistance for root development.

The soil density was the only physical attribute that correlated significantly with all the other attributes evaluated, indicating the importance of such attribute to assess soil quality to crops.

Areas that presented soil physical attributes similar to the Cerrado native area were: no-tillage system with 17 years, 5 years and the tillage system, respectively in this sequence (less similar).

Changes caused by the anthropic activity in soil physical attributes are more pronounced and perceptible in soil depths up to $0.2 \mathrm{~m}$.

\section{References}

Arshad, M. A., Lowery, B., \& Grossman, B. (1996). Physical tests for monitoring soil quality. In J. W. Doran \& A. J. Jones (Eds.), Methods for assessing soil quality (pp. 123-141). Soil Science Society of America Journal.

Bai, Z., Caspari, T., Gonzalez, M. R., Batjes, N. H., Mäder, P., Bünemann, E. K., ... Toth, Z. (2018). Effects of agricultural management practices on soil quality: A review of long-term experiments for Europe and China. Agriculture, Ecosystems \& Environment, 265, 1-7. https://doi.org/10.1016/j.agee.2018.05.028

Beck, H. E., Zimmermann, N. E., Mcvicar, T. R., Vergopolan, N., Berg, A., \& Wood, E. F. (2018). Present and future Köppen-Geiger climate classification maps at 1-km resolution. Scientific Data, 1, 1-12, 2018. https://doi.org/10.1038/sdata.2018.214

Bertol, I., Albuquerque, J. A., Leite, D., Amaral, A. J., \& Zoldan Junior, W. A. (2004). Propriedades físicas do solo sob preparo convencional e semeadura direta em rotação e sucessão de culturas, comparadas às do 
campo nativo. Revista Brasileira de Ciências do Solo, 28, 155-163. https://doi.org/10.1590/S0100-06832 004000100015

Beutler, A. N., Centurion, J. F., Centurion, M. A. P. C., \& Silva, A. P. (2006). Efeito da compactação na produtividade de cultivares de soja em Latossolo Vermelho. Revista Brasileira de Ciência do Solo, 30, 787-794. https://doi.org/10.1590/S0100-06832006000500004

Bolinder, M. A., Angers, D. A., Gregorich, E. G., \& Carter, M. R. (1999). The response of soil quality indicators to conservation manage. Canadian Journal of Soil Science, 79(1), 37-45. https://doi.org/10.4141/S97-099

Carvalho, J. L. N., Avanzi, J, C., Silva, M. L. N., Mello, C. R., \& Cerri, C. E. P. (2010). Potencial de sequestro de carbono em diferentes biomas do Brasil. Revista Brasileira de Ciências do Solo, 34, 277-289. https://doi.org/10.1590/S0100-06832010000200001

Demarchi, J. C., Perusi, M. C., \& Piroli, E. D. (2011). Análise da estabilidade de agregados de solos da microbacia do Ribeirão São Domingos, Santa Cruz do Rio Pardo-SP, sob diferentes tipos de uso e ocupação. Revista Brasileira de Tecnologia Aplicada nas Ciências Agrárias, 4, 7-29. https://doi.org/10.5777/ PAeT.V4.N2.01

Ferreira, F. P., Azevedo, A. C., Dalmolin, R. S. D., \& Girelli, D. (2007). Carbono orgânico, óxidos de ferro e distribuição de agregados em dois solos derivados de basalto no Rio Grande do Sul-Brasil. Ciência Rural, 37, 381-388. https://doi.org/10.1590/S0103-84782007000200013

Freddi, O. S., Carvalho, M. P., Veronesi Júnior, V., \& Carvalho, G. J. (2006). Produtividade do milho relacionada com a resistência mecânica à penetração do solo sob preparo convencional. Engenharia Agrícola, 26, 113-121. https://doi.org/10.1590/S0100-69162006000100013

Girardello, V. C., Amado, T. J. C., Santi, A. L., Cherubin, M. R., Kunz, J., \& Teixeira, T. G. (2014). Resistência à penetração, eficiência de escarificadores mecânicos e produtividade da soja em Latossolo argiloso manejado sob plantio direto de longa duração. Revista Brasileira de Ciência do Solo, 38(4), 1234-1244. https://doi.org/10.1590/S0100-06832014000400020

Hernani, L. C., \& Salton, J. C. (2009). Atributos de solo e produtividade de culturas em sistemas de manejo conduzidos por dezesseis anos. EMBRAPA-Boletim de Pesquisa e Desenvolvimento, 54, 1-63. https://doi.org/10.1590/01000683rbcs20140597

Hickmann, C., Costa, L. M., Schaefer, C. E. G., Fernandes, R. B. A., \& Andrade, C. L. T. (2012). Atributos físico-hidricos e carbono orgânico de um argissolo após 23 anos de diferentes manejos. Revista Caatinga, 25(1), 128-136.

INMET (Instituto Nacional de Meteorologia). (2018). Informações sobre as condições climáticas do município de Uberaba-MG. Retrieved from http://www.inmet.gov.br

Kemper, W. D., \& Chepil, W. S. (1965). Aggregate stability and size distribution. In: Black, C.A. (ed.) Methods of soils analysis. American Society of Agronomy, 39, 499-510.

Kiehl, E. J. (1979). Manual de edafologia: Relações solo-planta. Ceres, São Paulo.

Lago, W. N. M., Lacerda, M. P. C., \& Neumann, M. R. B. (2012). Indicadores de qualidade dos solos na microbacia do Ribeirão Extrema, DF: Parte II. Revista Brasileira de Engenharia Agrícola e Ambiental, 16, 721-729. https://doi.org/10.1590/S1415-43662012000700004

Lima, J. S. S., Silva, S. A., \& Silva, J. M. (2013). Variabilidade espacial de atributos químicos de um Latossolo Vermelho-Amarelo cultivado em plantio direto. Revista de Ciências Agroambientais, 44, 16-23. https://doi.org/10.1590/S1806-66902013000100003

Loss, A., Pereira, M. G., Anjos, L. H. C., Beutler, S. J., Ferreira, E. P., \& Silva, E. M. R. (2011). Oxidizable organic carbon fractions and soil aggregation in areas under different organic production systems in Rio de Janeiro, Brazil. Tropical and Subtropical Agroecosystems, 14, 699-708.

Loss, A., Pereira, M. G., Beutler, S. J., Perin, A., Picollo, M. C., Assuncao, S. A., \& Zonta, E. (2019). The impact of agricultural systems in the soil organic matter content in Brazilian Cerrado. International Journal of Research, Granthaalayah, 7, 220-244. https://doi.org/10.5281/zenodo.3381320

Loss, A., Pereira, M. G., Perin, A., \& Anjos, L. H. C. (2012). Carbon and nitrogen content and stock in no-tillage and crop-livestock integration systems in the Cerrado of Goias state, Brazil. Journal of Agricultural Science, 4, 96-105. https://doi.org/10.5539/jas.v4n8p96 
Loss, A., Pereira, M. G., Schultz, N., Ferreira, E. P., Silva, E. M. R., \& Beutler, S. J. (2009). Distribuição dos agregados e carbono orgânico influenciados por manejos agroecológicos. Acta Scientiarum-Agronomy, 31, 523-528. https://doi.org/10.4025/actasciagron.v31i3.322

Mazetto Júnior, J. C., Torres, J. L. R., Costa, D. D. D., Silva, V. R., Souza, Z. M., \& Lemes, E. M. (2019). Production and decomposition of cover crop residues and associations with soil organic fractions. Journal of Agricultural Science, 11(5), 1-17. https://doi.org/10.5539/jas.v11n5p58

Mcphee, J. E., Aird, P. L., Hardie, M. A., \& Corkrey, S. R. (2015). The effect of controlled traffic on soil physical properties and tillage requirements for vegetable production. Soil Tillage Research, 149, 33-45. https://doi.org/10.1016/j.still.2014.12.018

Michelon, C. J., Carlesso, R., Petry, M. T., David, G., \& Santa, C. L. (2007). Qualidade física de solos irrigados do estado do Rio Grande do Sul. Ciência Rural, 37(5), 1308-1315. https://doi.org/10.1590/S0103-84782 007000500014

Moraes, M. T., Debiasi, H., Carlesso, R., Franchini, J. C., Silva, V. R., \& Luz, F. B. (2016). Soil physical quality on tillage and cropping systems after two decades in the subtropical region of Brazil. Soil Tillage Research, 155, 351-362. https://doi.org/10.1016/j.still.2015.07.015

Ordoñez-Morales, K. D., Cadena-Zapata, M., Zermeño-González, A., \& Campos-Magaña, S. (2019). Effect of tillage systems on physical properties of a clay loam soil under oats. Agriculture, 9(3), 62. https://doi.org/10.3390/agriculture9030062

Pezarico, C. R., Vitorino, A. C. T., Mercante, F. M., \& Daniel, O. (2013). Indicadores de qualidade do solo em sistemas agroflorestais. Revista Ciência Agronômica, 56, 40-7. https://doi.org/10.4322/rca.2013.004

Pinheiro, E. F. M., Pereira, M. G., \& Anjos, L. H. C. (2004). Aggregates distribution and soil organic matter under different tillage system for vegetable crops in a Red Latosol from Brazil. Soil Tillage Research, 77, 79-84. https://doi.org/10.1016/j.still.2003.11.005

Ralisch, R., Miranda, T. M., Okumura, R. S., Barbosa, G. M. C., Guimarães, M. F., Scopel, E., \& Balbino, L. C. (2008). Resistência à penetração de um Latossolo Vermelho Amarelo do Cerrado sob diferentes sistemas de manejo. Revista Brasileira de Engenharia Agrícola e Ambiental, 12(4), 381-384. https://doi.org/ 10.1590/S1415-43662008000400008

Reichert, J. M., Suzuki, L. E. A. S., Reinert, D. J., Horn, R., \& Håkansson, I. (2009). Reference bulk density and critical degree-of-compactness for no-till crop production in subtropical highly weathered soils. Soil Tillage Research, 102, 242-254. https://doi.org/10.1016/j.still.2008.07.002

Reinert, D. J., Albuquerque, J. A., Reichert, J. M., Aita, C., \& Andrada, M. M. C. (2008). Limites críticos de densidade do solo para o crescimento de raízes de plantas de cobertura em Argissolo Vermelho. Revista Brasileira de Ciências do Solo, 32, 1805-1816. https://doi.org/10.1590/S0100-06832008000500002

Reis, D. A., Lima, C. L. R., \& Bamberg, A. L. (2016). Qualidade física e frações da matéria orgânica de um Planossolo sob sistema plantio direto. Pesquisa Agropecuária Brasileira, 51(9), 1623-1632. https://doi.org/ 10.1590/s0100-204x2016000900062

Rodrigues, M., Rabêlo, F. H. S., Castro, H. A., Roboredo, D., Carvalho, M. A. C., \& Roque, C. G. (2018). Cultivo mínimo é o sistema recomendado para introdução da Brachiaria brizantha em Latossolo na Amazônia. Revista Ciência Agronômica, 61, 2-7. https://doi.org/10.22491/rca.2018.2808

Rossetti, K. V., Andrioli, I., Centurion, J. F., Matias, S. S. R., \& Nobrega, J. C. A. (2012). Atributos físicos do solo em diferentes condições de cobertura vegetal em área de plantio direto. Revista Brasileira de Ciências Agrárias, 7(3), 426-432. https://doi.org/10.5039/agraria.v7i3a1681

Sá, J. C. M., Cerri, C. C., Piccolo, M. C., Feigl, B. E., Fornari, A., Sá, M. F. M., ... Paulleti, V. (2004). O plantio direto como base do sistema de produção visando o sequestro de carbono. Plantio Direto, 84, 45-61.

Santos, F. S., Zanão Junior, L. A., Secco, D., Dias, P. P., Tomassoni, F., \& Pereira, N. (2014). A utilização de plantas de cobertura na recuperação de solos compactados. Acta Iguazu, 3, 82-91.

Santos, H. G., Jacomine, P. K. T., Anjos, L. H. C., Oliveira, V. A., Lumbreras, J. F., Coelho, M. R., ... Oliveira, J. B. (2013). Sistema brasileiro de classificação de solos (3rd ed.). Embrapa, Brasília.

Sene, M., Vepraskas, M. J., Naderman, G. C., \& Denton, H. P. (1985). Relationships of soil texture and structure to corn yield response to subsoiling. Soil Science Society of America Journal, 49, 422-427. https://doi.org/ $10.2136 /$ sssaj1985.03615995004900020030x 
Silva, G. J., Valadão Júnior, D. D., Bianchini, A., Azevedo, E. C., \& Maia, J. C. S. (2008). Variação de atributos físico-hídricos em Latossolo Vermelho-Amarelo do Cerrado mato-grossense sob diferentes formas de uso. Revista Brasileira de Ciências do Solo, 32(5), 2135-2143. https://doi.org/10.1590/S0100-06832008000 500034

Silva, R., \& Rosolem, C. (2001). Crescimento radicular de espécies utilizadas como cobertura decorrente da compactação do solo. Revista Brasileira de Ciência do Solo, 25(2), 253-260. https://doi.org/10.1590/ S0100-06832001000200001

Silveira, P. M., Silva, J. H., Lobo Junior, M., \& Cunha, P. C. R. (2011). Atributos do solo e produtividade do milho e do feijoeiro irrigado sob sistema integração lavoura pecuária. Pesquisa Agropecuária Brasileira, 46(10), 1170-1175. https://doi.org/10.1590/S0100-204X2011001000008

Stolf, R., Murakami, J. H., Brugnaro, C., Silva, L. G., \& Margarido L. A. C. (2014). Penetrômetro de impacto Stolf-programa computacional de dados em EXCEL-VBA. Revista Brasileira de Ciências do Solo, 38, 774-782. https://doi.org/10.1590/S0100-06832014000300009

Stone, L. F., Silveira, P. M., \& Moreira, J. A. (2006). Atributos físico-hídricos do solo sob plantio direto. Embrapa Arroz e Feijão (Documento 191).

Suzuki, L. E. A. S., Reichert, J. M., Reinert, D. J., \& Lima, C. L. R. (2007). Grau de compactação, propriedades físicas e rendimento de culturas em Latossolo e Argissolo. Pesquisa Agropecuária Brasileira, 42, 1159-1167. https://doi.org/10.1590/S0100-204X2007000800013

Tavares Filho, J., \& Tessier, D. (2009). Compressibility of Oxisol aggregates under no-till in response to soil water potential. Revista Brasileira de Ciências do Solo, 33, 1525-1533. https://doi.org/10.1590/S0100-068 32009000600002

Taylor, S. A., \& Ashcroft, G. L. (1972). Physical edaphology—The physics of irrigated and non-irrigated soils. W.H. Freeman, San Francisco.

Teixeira, P. C., Donagemma, G. K., Fontana, A., \& Teixeira, W. G. (2017). Manual de métodos de análise de solos (3rd ed.). Embrapa, Rio de Janeiro.

Tesfahunegn, G. B., \& Gebru, T. A. (2020) Variation in soil properties under different cropping and other land-use systems in Dura catchment, Northern Ethiopia. PLoS ONE, 15(2), e0222476. https://doi.org/ 10.1371/journal.pone.0222476

Torres, J. L. R., Costa, D. D. A., Silva Neto, O. F., Araújo, A. S., Silva, V. R., \& Vieira, D. M. S. (2015b). Avaliação da resistência à penetração e densidade do solo num Latossolo sob semeadura direta há doze anos. Global Science and Tecnology, 8(01), 131-140. https://doi.org/10.14688/1984-3801/gst.v8n1p131-140

Torres, J. L. R., Fabian, A. J., \& Pereira, M. G. (2011). Alterações dos atributos físicos de um Latossolo Vermelho submetido a diferentes sistemas de manejo. Ciência e Agrotecnologia, 35, 437-445. https://doi.org/10.1590/S1413-70542011000300001

Torres, J. L. R., Mazetto Júnior, J. C., Silva Júnior, J., Vieira, D. M. S., Souza, Z. M., Assis, R. L., \& Lemes, E. M. (2019). Soil physical attributes and organic matter accumulation under no-tillage systems in the Cerrado. Soil Research, 57(7), 712-718. https://doi.org/10.1071/SR19047

Torres, J. L. R., Pereira, M. G., Assis, R. L., \& Souza, Z. M. (2015a). Atributos físicos de um latossolo vermelho cultivado com plantas de cobertura, em semeadura direta. Revista Brasileira de Ciências do Solo, 39, 428-437. https://doi.org/10.1590/01000683rbcs20140597

Viana, E. T., Batista, M. A., Tormena, C. A., Costa, A. C. S., \& Inoue, T. T. (2011). Atributos físicos e carbono orgânico em Latossolo Vermelho sob diferentes sistemas de uso e manejo. Revista Brasileira de Ciências do Solo, 35, 2105-2114. https://doi.org/10.1590/S0100-06832011000600025

Wendling, B., Jucksch, I., Mendonça, E. S., \& Neves J. C. L. (2005). Carbono orgânico e estabilidade de agregados de um Latossolo Vermelho sob diferentes manejos. Pesquisa Agropecuária Brasileira, 40, 487-494. https://doi.org/10.1590/S0100-204X2005000500010 


\section{Copyrights}

Copyright for this article is retained by the author(s), with first publication rights granted to the journal.

This is an open-access article distributed under the terms and conditions of the Creative Commons Attribution license (http://creativecommons.org/licenses/by/4.0/). 